\title{
O.S.P.
}

L'orientation scolaire et professionnelle

$29 / 2 \mid 2000$

Diplôme et marché du travail

\section{R., Boyer, \& Ch., Coridian. Modes de vie collégiens et lycéens.}

INPR

Monique Wach

\section{OpenEdition}

Journals

Édition électronique

URL : http://journals.openedition.org/osp/5962

DOI : $10.4000 /$ osp.5962

ISSN : 2104-3795

Éditeur

Institut national d'étude du travail et d'orientation professionnelle (INETOP)

Édition imprimée

Date de publication : 15 juin 2000

ISSN : 0249-6739

\section{Référence électronique}

Monique Wach, «R., Boyer, \& Ch., Coridian. Modes de vie collégiens et lycéens. », L'orientation scolaire

et professionnelle [En ligne], 29/2 | 2000, mis en ligne le 04 juin 2018, consulté le 23 octobre 2020.

URL : http://journals.openedition.org/osp/5962 ; DOI : https://doi.org/10.4000/osp.5962

Ce document a été généré automatiquement le 23 octobre 2020

(c) Tous droits réservés 


\title{
R., Boyer, \& Ch., Coridian. Modes de vie collégiens et lycéens.
}

INPR

\author{
Monique Wach
}

\section{RÉFÉRENCE}

INPR

Boyer, R., \& Coridian, Ch. (coordonné par). Modes de vie collégiens et lycéens. I.N.P.R. avril 2000.

1 Cet ouvrage donne quelques éclairages synthétiques sur divers aspects de la vie des jeunes. La dispersion et la spécialisation des travaux ne permettent pas, en général, de trouver réuni dans un seul ouvrage, ces différentes approches. Dans ce panorama, les contributions viennent de divers horizons et le mode de vie en est le fédérateur.

2 Le premier chapitre dresse un panorama de l'enseignement, et des conditions de vie familiale, en insistant sur les nouvelles tendances.

3 Un second chapitre, fort intéressant, analyse ce qu'on peut appeler « le métier d'élève ", et donne des informations sur le rapport, souvent « utilitariste », de certains jeunes, aux études ; « Ils sont assez doués en calcul ».

4 Les chapitres qui suivent abordent les univers culturels, l'argent, la santé ainsi que leurs valeurs et croyances. 